\title{
Plankton community structure and carbon cycling off the western coast of Greenland, with emphasis on sources of DOM for the bacterial community
}

\author{
Eva Friis Møller*, Torkel Gissel Nielsen
}

\author{
National Environmental Research Institute, Department of Marine Ecology, Frederiksborgvej 399, PO Box 358 , \\ 4000 Roskilde, Denmark
}

\begin{abstract}
The plankton community was investigated in Disko Bay, West Greenland, in August 1998, and the importance of phytoplankton versus zooplankton in providing substrates for the bacterial community was evaluated. Two distinct plankton communities were observed. In the stratified north side of the bay the surface water was nutrient depleted and high biomasses of phyto-, zoo- and bacterioplankton were observed; in contrast, the south side had less pronounced stratification, higher concentrations of nutrients and lower plankton biomass levels. Accompanying differences in the relative importance of the different sources of substrates for the bacteria were indicated from carbon flow scenarios and correlations between bacterial production and plankton biomass. These showed that the protozooplankton were most important in the north, while in the south the contributions from phytoplankton and zooplankton to the bacteria substrate pool were equal. Overall, the ciliates and heterotrophic dinoflagellates played a key role as grazers and in providing substrates for the bacteria in this arctic ecosystem.
\end{abstract}

KEY WORDS: Arctic microbial ecology $\cdot$ DOM production $\cdot$ Bacteria $\cdot$ Protozooplankton $\cdot$ Copepods

Resale or republication not permitted without written consent of the publisher

\section{INTRODUCTION}

Of central importance in research on cycling of organic matter in arctic marine food webs is the role of bacteria. Bacterial production has been suggested as being uncoupled from primary production during the spring bloom in cold areas because temperatures near zero inhibit bacterial metabolism more than primary production (Pomeroy \& Deibel 1986). If this is true, this would lead to a larger fraction of primary production being directly available to planktonic grazers and the benthic community (Pomeroy \& Wiebe 1988). Others have stated that the trophic structure of the pelagic community leading to differences in availability and composition of substrates for bacteria may be equally or more important than temperature (Pomeroy et al. 1991, Thingstad \& Martinussen 1991, Yager \& Deming 1999). During the arctic summer, however, the role temperature plays in controlling bac-

*E-mail: efm@dmu.dk terial production will probably be less important since the surface waters are often well above zero.

Generally, correlations are found between bacterial production and chlorophyll a $(\mathrm{chl}$ a) and primary production (Cole et al. 1988). However, in most pelagic systems less than half of the bacterial carbon demand can be sustained by release of carbon directly from phytoplankton (Baines \& Pace 1991). Studies have demonstrated that release by zooplankton grazing contributes to the pool of dissolved organic material (DOM). Theoretical arguments by Jumars et al. (1989) suggest that leaking from fecal pellets may be important especially during times of high food availability. Laboratory experiments have shown that, due to sloppy feeding, the DOM contribution from copepods is important when phytoplankton cells are large (E.F.M. \& T.G.N. unpubl.). The production of DOM by protozooplankton is documented for nanoflagellates and dinoflagellates (Nagata \& Kirchman 1992, Tranvik 1994, Strom et al. 1997, Ferrier-Pagès et al. 1998) and for ciliates (Strom et al. 1997, Ferrier-Pagès et al. 1998). 
Field studies and mesocosm experiments investigating the importance of zooplankton grazing for DOM production in marine waters have focused on the effects of copepods. Correlations have been found between copepod abundance and amino acid concentration in the water column (Poulet et al. 1991), and the presence of copepods has been shown to stimulate bacterial production (Eppley et al. 1981, Roman et al. 1988, Peduzzi \& Herndl 1992). Evaluating the importance of protozooplankton in natural environments is a more difficult task due to the size overlap with the phytoplankton.

In arctic marine systems, the significance of protozooplankton in the planktonic food web has been documented as being comparable to that in temperate areas (Andersen 1988, Nielsen \& Hansen 1995, Sherr et al. 1997, Levinsen et al. 1999). A main difference in the annual cycle between the 2 latitudes is the reduced top-down control of the plankton community in the late summer in the arctic areas (Hansen et al. 1999). The population of the large copepods (Calanus spp.) migrates to the deep water and starts hibernation around midsummer, thus leaving the productive layers for protozooplankton and smaller copepod stages and species (Hansen et al. 1999). It is therefore hypothesised that small grazers are of importance not only as grazers but also as producers of bacterial substrate during late summer.

The present study investigates the plankton community structure in Disko Bay during the late arctic summer with special emphasis on the potential sources of substrates for the bacterial community.

\section{MATERIALS AND METHODS}

Study site. The present study was conducted on a cruise of the RV 'Adolf Jensen' (Grønlands Naturinstitut, Nuuk) from 20 to 25 August 1998 along a transect across the entrance of Disko Bay, West Greenland (Fig. 1).

Hydrography. Vertical profiles of temperature, salinity, fluorescence and light intensity were obtained from the surface to $120 \mathrm{~m}$ with a Seabird CTD system equipped with a fluorometer. The in situ fluorometer measurements were calibrated against spectrophotometrically determined chl a content in the water samples and a linear regression was conducted $\left(n=43, r^{2}=\right.$ $0.61, \mathrm{p}<0.01)$. Based on the water column structure and fluorescence profiles, 3 to 5 depths were selected for biological and chemical measurements. Water sam-
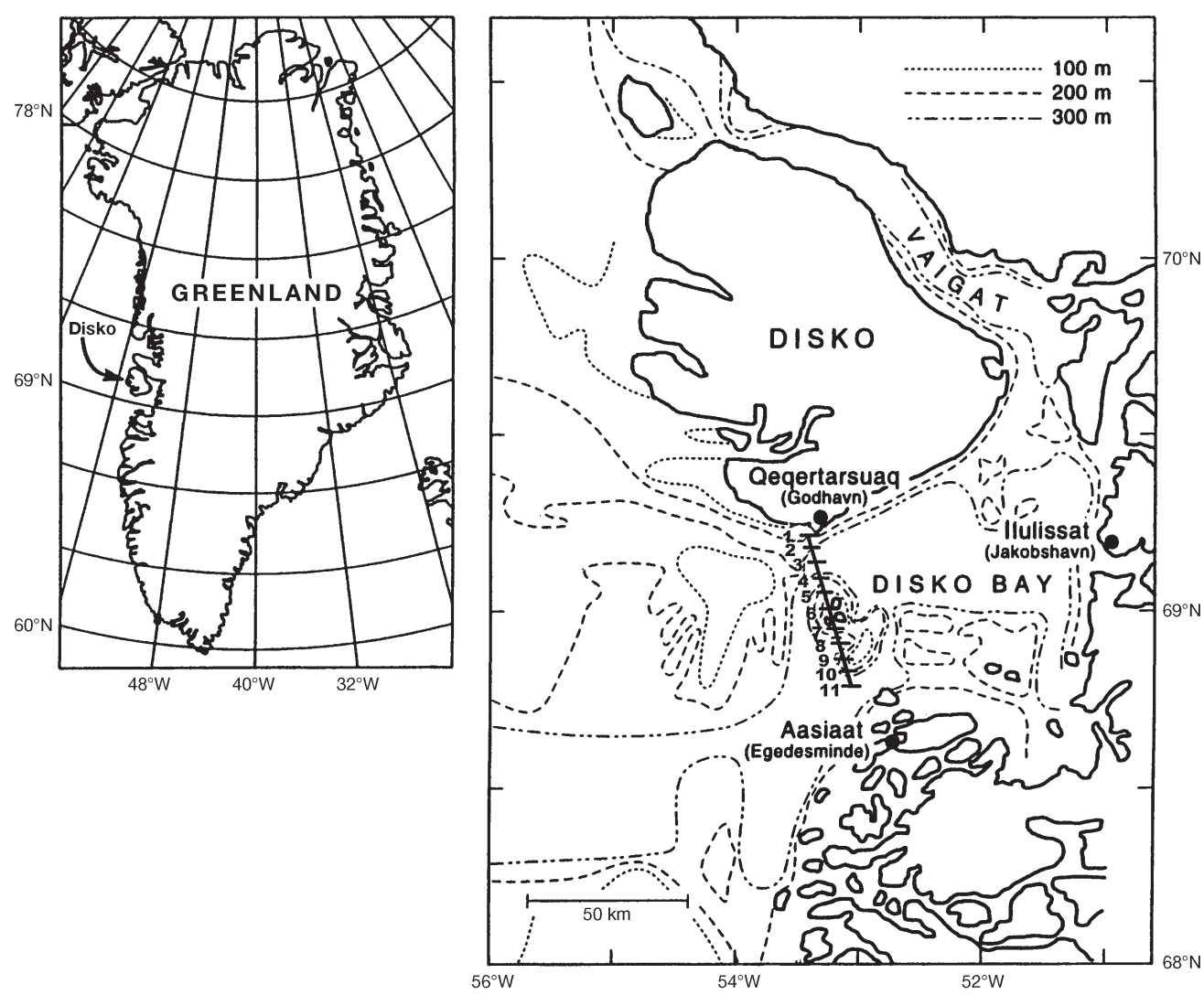

Fig. 1. Map showing the location of Disko Bay and the position of the transect studied August 1998 
ples were collected using Niskin bottles equipped with Teflon-coated springs. Irradiance data were obtained from the Arctic Station, Qeqertarsuaq, University of Copenhagen.

Nutrients. Samples for determination of nutrient concentrations $\left(\mathrm{NH}_{4}{ }^{+}, \mathrm{NO}_{2}{ }^{-}, \mathrm{NO}_{3}{ }^{-}, \mathrm{PO}_{4}{ }^{3-}\right.$, and $\left.\mathrm{SiO}_{4}{ }^{3-}\right)$ were frozen immediately. Measurements were carried out at the National Environmental Research Institute, Roskilde, Denmark, on an automatic nutrient analyzer following Grashoff (1976). The detection limits were 0.6, $0.03,0.06,0.09$ and $0.12 \mu \mathrm{M}$ for $\mathrm{NH}_{4}{ }^{+}, \mathrm{NO}_{2}{ }^{-}, \mathrm{NO}_{3}{ }^{-}$, $\mathrm{PO}_{4}{ }^{3-}$ and $\mathrm{SiO}_{4}{ }^{3-}$, respectively.

Phytoplankton. Samples for chl a measurements were placed in the dark and filtered within $1 \mathrm{~h}$ in duplicates onto GF/F, 11 and $45 \mu \mathrm{m}$ filters, extracted in $96 \%$ ethanol (Jespersen \& Christoffersen 1987) and measured spectrophotometrically (Strickland \& Parsons 1968). A conversion factor for chl a to carbon of 43 determined in Disko Bay during the late summer of 1994 was applied (Nielsen \& Hansen 1999). Phytoplankton abundance and species composition were determined by inverted microscopy using samples preserved with Lugol's solution (3\% final concentration) collected from the surface and fluorescence maximum of 4 selected stations.

Primary production was calculated using field measurements of phytoplankton biomass, underwater irradiance, and parameters of light-saturated photosynthesis $\left(P_{\max }\right)$ and light limitation $(\alpha)$ from Markager et al. (1999). Those authors reviewed photosynthetic parameters in waters between -2 and $6^{\circ} \mathrm{C}$ and found a mean of $P_{\max }=1.38 \pm 0.89$ (SD) g C g ${ }^{-1} \mathrm{chl} a \mathrm{~h}^{-1}$ and

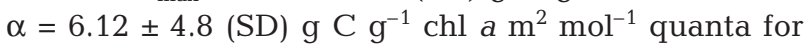
marine phytoplankton.

Bacteria. Samples for bacteria biomass were placed in $20 \mathrm{ml}$ vials and fixed with buffered formalin $(2 \%$ final concentration). Samples were filtered onto $0.2 \mu \mathrm{m}$ black polycarbonate filters and stained using acridine orange (Hobbie et al. 1977). At least 400 cells were counted per filter. The cell volume was estimated by length and width measurements of 50 cells per filter and converted to carbon using a conversion factor of $0.22 \mathrm{pg} \mathrm{C} \mathrm{\mu m}^{-3}$ (Bratbak \& Dundas 1984).

Bacterial production was measured by the incorporation of ${ }^{14} \mathrm{C}$-leucine (Kirchman et al. 1985) and ${ }^{3} \mathrm{H}$ thymidine (Fuhrman \& Azam 1982). Immediately after sampling, triplicate samples were incubated with $50 \mathrm{nM}$ ${ }^{14} \mathrm{C}$-leucine and $0.1 \mathrm{nM}{ }^{3} \mathrm{H}$-thymidine for $1 \mathrm{~h}$ at in situ surface water temperature. The thymidine concentration was intended to be $10 \mathrm{nM}$ but, by mistake, nonradioactive thymidine was not added. The incubations were stopped by the addition of buffered formalin ( $2 \%$ final concentration). Blanks were prepared by the addition of formalin prior to addition of isotopes. Samples were filtered onto $0.2 \mu \mathrm{m}$ cellulose nitrate filters, washed 10 times with ice-cold TCA and counted by liquid scintillation counting. The incorporated ${ }^{14} \mathrm{C}$ leucine was converted to carbon production by assuming that the fraction of leucine in protein is 0.073 and the fraction of carbon in protein is 0.86 (Simon \& Azam 1989). Isotope dilution measured in water samples near Stn 1 was 1.3 (W. Martinsen pers. comm.). The incorporated ${ }^{3} \mathrm{H}$-thymidine was converted to carbon production using a factor of $1.1 \times 10^{18}$ cells mol $^{-1}$ thymidine incorporated (Riemann et al. 1987) and a carbon

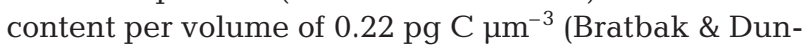
das 1984).

Heterotrophic nanoflagellates. Samples $(10 \mathrm{ml})$ from $10 \mathrm{~m}$ were fixed with buffered formalin ( $2 \%$ final concentration) and kept cold until preparation of the filters. Samples were filtered onto $0.8 \mu \mathrm{m}$ black polycarbonate filters and stained using proflavine (Haas 1982). The abundance and biovolume of heterotrophic nanoflagellates were determined by epifluorescence microscopy, examining the total filter and assuming a

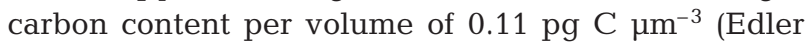
1979). The clearance rate was assumed to be $10^{5}$ body volume $\mathrm{h}^{-1}$ (Hansen et al. 1997).

Ciliates and heterotropic dinoflagellates. Samples from $1 \mathrm{~m}$, the depth of maximum fluorescence and $50 \mathrm{~m}$ were fixed in acid Lugol's solution ( $3 \%$ final concentration), and $50 \mathrm{ml}$ of each sample was counted after $24 \mathrm{~h}$ sedimentation using inverted microscopy. Cell volumes were estimated from linear dimensions assuming simple geometric shapes and converted to biomass using conversion factors of $0.11 \mathrm{pg} \mathrm{C}^{\mathrm{m}} \mathrm{m}^{-3}$ for ciliates and athecate dinoflagellates and $0.13 \mathrm{pg} \mathrm{C}$ $\mu^{-3}$ for thecate dinoflagellates (Edler 1979). The ingestion by ciliates and heterotrophic dinoflagellates was estimated from Levinsen et al. (1999) assuming a growth efficiency of $33 \%$ and converted to in situ temperature by a $Q_{10}$ of 2.8 (Hansen et al. 1997).

Mesozooplankton. Mesozooplankton were sampled by vertical hauls from $100 \mathrm{~m}$ to the surface with a WP2 net (200 $\mu \mathrm{m}$ mesh size). Sampling with a $200 \mu \mathrm{m}$ net may have led to loss of some of the smallest stages and species through the mesh (Hansen et al. 1999). Additional sampling was carried out with tows of a $45 \mu \mathrm{m}$ mesh net inserted in a $2 \mathrm{~m}$ ring net (custom-built). Samples were preserved in $4 \%$ buffered formalin and at least 400 individuals were identified and their length measured for each sample. The biomass was calculated from length:weight regressions from the literature according to Hansen et al. (1999).

Egg production experiments were conducted with Acartia longiremis (T.G.N. et al. unpubl. data). Zooplankton were collected from the upper $50 \mathrm{~m}$ with a $200 \mu \mathrm{m}$ net and a large non-filtering cod-end. The samples were diluted in surface water and brought to the laboratory. Three to 5 adult females were incu- 
bated in surface water in $600 \mathrm{ml}$ acid-cleaned polycarbonate bottles for $24 \mathrm{~h}$ at in situ surface temperature. The carbon content of eggs was calculated from egg volume assuming $0.14 \mathrm{pg} \mathrm{C} \mathrm{mm}^{-3}$ (Kiørboe et al. 1985). The specific egg production of $A$. longiremis was assumed to be representative of the growth rate of the copepod population, and community production was calculated as specific egg production $\times$ total biomass. Grazing rates were calculated from the specific production assuming a growth efficiency of $33 \%$ (Hansen et al. 1997).

Effect of copepods on dissolved organic carbon (DOC) production. The production of DOC by copepods was evaluated from their effect on the distribution of ${ }^{14} \mathrm{C}$ incorporated in different size fractions by primary production. Primary production was measured in triplicate $(60 \mathrm{ml})$ from the surface and the fluorescence maximum, respectively, with and without copepods. Prior to the experiments the water was reverse filtered $(<45 \mu \mathrm{m})$ to remove mesozooplankton grazers. Three female Acartia longiremis were then added. After $24 \mathrm{~h}$ incubation the added copepods and produced eggs were removed and counted and the samples were filtered in size fractions $(<0.2,0.2$ to 0.6 and $>0.6 \mu \mathrm{m}$ ).

To each bottle $0.17 \mu \mathrm{Ci} \mathrm{H}^{14} \mathrm{CO}_{3}{ }^{-} \mathrm{ml}^{-1}$ was added. One dark bottle $(40 \mathrm{ml})$ for each depth was incubated. The incubations were carried out in running surface seawater. Surface samples received natural light while samples from the fluorescence maximum were screened with a black cloth cover through which 1 to $2 \%$ of surface irradiance could penetrate.

After $24 \mathrm{~h}$, the incubations were stopped by placing bottles in the dark. Filtration began within $0.5 \mathrm{~h}$. Triplicate $18 \mathrm{ml}$ samples from each experiment were filtered sequentially through 0.6 and $0.2 \mu \mathrm{m}$ filters and the filtrate was collected in scintillation vials. Filters were also placed in glass scintillation vials. Corrections were made for the content of any organic ${ }^{14} \mathrm{C}$ in the added $\mathrm{H}^{14} \mathrm{CO}_{3}{ }^{-}$checked by addition of $500 \mathrm{\mu l} \mathrm{H}^{14} \mathrm{CO}_{3}{ }^{-}$ to $18 \mathrm{ml} \mathrm{GF/F}$ filtered seawater. Inorganic ${ }^{14} \mathrm{C}$ was removed by adding $300 \mu \mathrm{l} 1 \mathrm{~N} \mathrm{HCl}$ to each vial. All samples were frozen until further processing. Before liquid scintillation counting, the vials without lids were placed in a flow bench for $24 \mathrm{~h}$.

The ${ }^{14} \mathrm{C}$ activity collected on the 0.6 and $0.2 \mu \mathrm{m}$ filters was assumed to be associated with phytoplankton and bacteria, respectively. Bacteria may also have been retained on the $0.6 \mu \mathrm{m}$ filter. Sequential filtering of samples incubated for measuring bacterial production with ${ }^{3} \mathrm{H}$-thymidine through 0.6 and $0.2 \mu \mathrm{m}$ filters gave a correction for the distribution in each size fraction. By collecting $0.6 \mu \mathrm{m}$ filtrate on $0.2 \mu \mathrm{m}$ black polycarbonate filters, the appearance of autofluorescence, e.g. photosynthesizing organisms in the bacterial size frac- tion, was monitored. The part of primary production lost as DOC was calculated from the activity in the filtrate and the activity on the $0.2 \mu \mathrm{m}$ filter corrected for the loss of bacteria on the $0.6 \mu \mathrm{m}$ filter. A bacterial growth efficiency of $40 \%$ was assumed (Bjørnsen \& Kuparinen 1991).

The difference between the part of primary production lost as DOC in the incubations with and without added copepods was assumed to be caused by copepod feeding activity. This difference was compared to the ingestion by the copepods calculated from egg production, thereby achieving an estimate of the fraction of ingestion that was lost as DOC. Since copepods ingest phytoplankton cells and not only the ${ }^{14} \mathrm{C}$ marked fraction, the specific uptake rates determined in the control primary production bottles were used to calculate the actual DOC loss.

\section{RESULTS}

\section{Water column structure and nutrients}

The Polar Current enters Disko Bay in the southern part, where a sill forces the deep water into the euphotic zone (Fig. 1) (Munk et al. unpubl.). The water leaves the bay through Vaigat passage and, following a cyclonic circulation, it also leaves through the northern part of the bay. The northern part of the bay is influenced by meltwater from the glacier at Ilulissat, which creates a low salinity surface layer that extends through the northern part of the bay (Nielsen \& Hansen 1995, 1999). These hydrographic characteristics influence the water column structure and create a pronounced north-south difference along the transect. Stns 1 to 4 and Stns 7 to 11, which are north and south of the islands 'Hundeøerne', respectively, will hereafter be referred to as the northern and southern parts of the bay.

In the southern part of the bay the water temperature was between 4 and $6^{\circ} \mathrm{C}$ in the upper $50 \mathrm{~m}$ (Fig. 2A) and the salinity increased from 32.6 psu at the surface to $33.6 \mathrm{psu}$ at $50 \mathrm{~m}$ (Fig. 2B). In the northern region higher temperatures and lower salinity were observed in the surface waters and the vertical gradient of both variables was more pronounced, leading to a stronger stratification in the northern than the southern part of the bay (Fig. 2C).

The nutrient concentrations (Fig. 3) mirrored the salinity gradients. Nutrient concentrations were low or undetectable in and above the fluorescence maximum in the northern parts of the bay, whereas in the southern part, surface nutrient levels were generally high (Fig. 3). The distribution of $\mathrm{NO}_{2}^{-}$resembled that of $\mathrm{NO}_{3}^{-}$, and $\mathrm{NO}_{2}^{-}$constituted $<7 \%$ of the inorganic $\mathrm{N}$ 

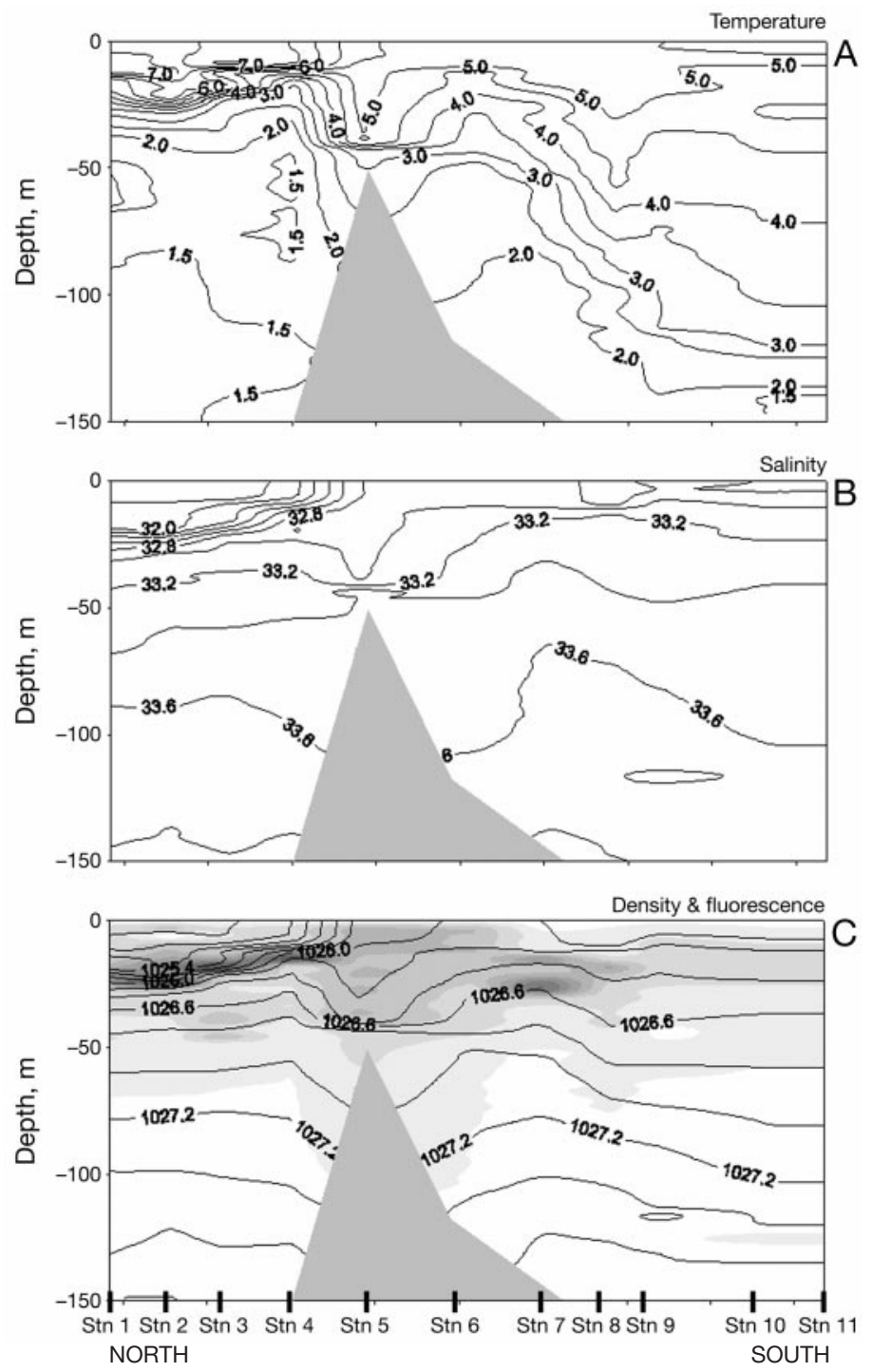

Fig. 2. Distribution of (A) temperature $\left({ }^{\circ} \mathrm{C}\right)$, (B) salinity $(\%)$, and $(\mathrm{C})$ fluorescence (arbitrary units) and density along the transect

pool. $\mathrm{NH}_{4}{ }^{+}$was not detectable in the northern part of the bay but constituted up to one-third of the total pool of inorganic nitrogen in the southern part.

\section{Phytoplankton}

A prominent feature along the transect was the subsurface chl a maximum (Fig. 2C). The highest phytoplankton biomass of up to $200 \mu \mathrm{C} \mathrm{Cl}^{-1}$ was recorded in the northern part of the bay. In the southern part of the

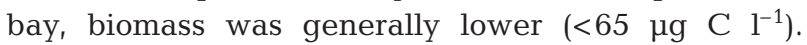
Phytoplankton size distribution was generally shared equally between cells larger and smaller than $11 \mu \mathrm{m}$, except for Stns 9 and 11, where cells $<11 \mu \mathrm{m}$ dominated (Fig. 4). The species composition of large phytoplankton was evaluated at Stns 1, 3, 7 and 11. In the northern part the fraction $>11 \mu \mathrm{m}$ was dominated ( $>95 \%$ ) by a mixture of centric diatoms (Thalassiosira spp. and Chaetoceros spp.) and thecate dinoflagellates. In the southern part the fraction $>11 \mu \mathrm{m}$ was primarily chain forming or elongated centric diatoms (Chaetoceros spp. and Rhizosolenia spp.). There were no differences in the species composition between the surface layer and the layer of maximum fluorescence. The autotrophic nanoflagellates were dominated by dinoflagellates (58 $\pm 6[\mathrm{SE}] \%)$ with a smaller contribution from chrysophyceae and at Stns 9 and 11 from haptophyceae.

\section{Bacteria}

As for phytoplankton, the maximum biomass of bacteria was found in the northern part of the bay (Fig. 5A). The abundance of bacteria ranged between $3.1 \times 10^{5}$ and $1.1 \times 10^{6}$ cells ml $^{-1}$ (data not shown). The average bacterial cell size was $0.094 \pm 0.003$ (SE) $\mu \mathrm{m}^{3}$. No trends were found in the distribution of bacterial cell size, and the distribution of bacterial biomass followed the abundance.

Bacterial production was highest in the surface water and decreased towards the bottom. The highest values $\left(\sim 10 \mu \mathrm{g} \mathrm{C} \mathrm{l}^{-1} \mathrm{~d}^{-1}\right)$ were found in the northern part of the bay (Fig. 5B), while lower values (up to $3.7 \mu \mathrm{C} \mathrm{Cl}^{-1} \mathrm{~d}^{-1}$ ) were found in the southern part. There is a linear correlation of $y=5.3 x+0.9\left(r^{2}=0.90, p<0.01\right)$ between bacterial production calculated on the basis of incorporation $\left(\mu \mathrm{g} \mathrm{C} \mathrm{l}^{-1} \mathrm{~d}^{-1}\right)$ of ${ }^{14} \mathrm{C}$-leucine and ${ }^{3} \mathrm{H}$-thymidine (Fig. 6).

\section{Heterotrophic nanoflagellates}

The average biomass of heterotrophic nanoflagellates (excluding the dinoflagellates) in the northern $\left(0.12 \pm 0.02[\mathrm{SE}] \mu \mathrm{g} \mathrm{Cl}^{-1}\right)$ and southern parts $(0.11 \pm 0.03$ [SE] $\mu \mathrm{g} \mathrm{C}^{-1}$ ) (data not shown) were not statistically different ( $t$-test, $\mathrm{p}=0.46$ ); the biomass of heterotrophic nanodinoflagellates was $0.39 \pm 0.06$ (SE) $\mu g \mathrm{C} \mathrm{l}^{-1}$ and $0.21 \pm 0.06[\mathrm{SE}] \mu \mathrm{g} \mathrm{C} \mathrm{^{-1 }}$, respectively.

\section{Ciliates and heterotrophic dinoflagellates}

Biomass of ciliates and heterotrophic dinoflagellates peaked in the surface layers (Fig. 7) in contrast to their potential food source of phytoplankton, which peaked at the pycnocline (Figs. $2 \& 4$ ). Assuming the same 

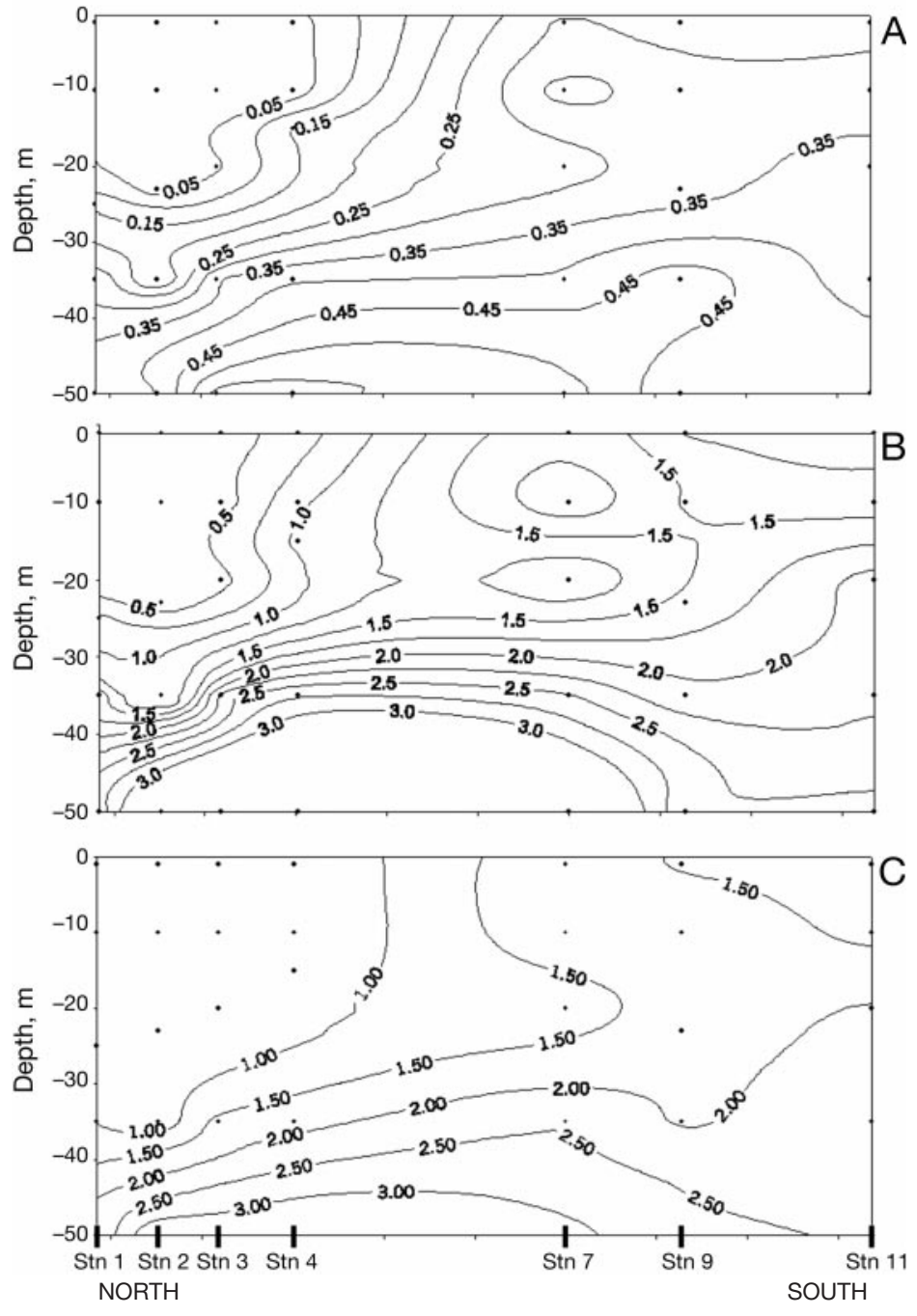

Fig. 3. Distribution of (A) phosphate $(\mu \mathrm{M})$, (B) nitrate + nitrite $(\mu \mathrm{M})$, and $(\mathrm{C})$ silicate $(\mu \mathrm{M})$ along the transect

chl $a$ to carbon ratio as for the phytoplankton the potentially mixotrophic ciliates Mesodinium rubrum, Laboea strobila and Tontonia spp. might have contributed substantially to the phytoplankton biomass with up to $33 \%$.

The highest biomass values (up to $69 \mu \mathrm{g} \mathrm{Cl}^{-1}, \sim 32$ cells $\mathrm{ml}^{-1}$ ) (Fig. 7) of ciliates and heterotrophic dinoflagel-

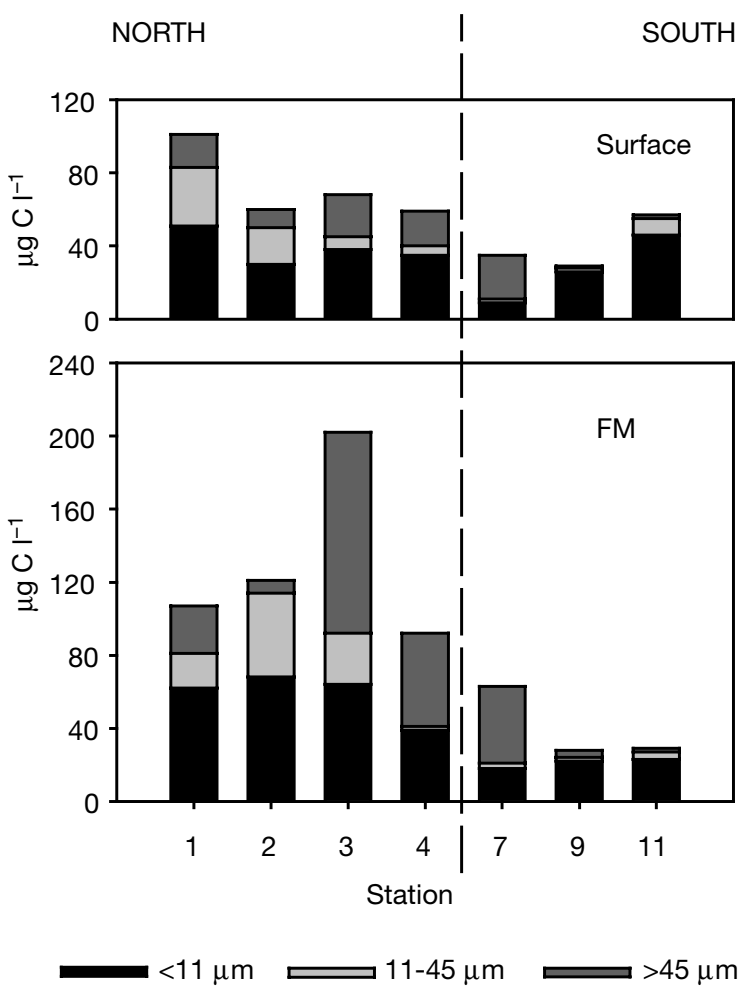

Fig. 4. Size distribution of phytoplankton in (A) surface waters and (B) at the depth of maximum fluorescence

lates were found in the northern part of the bay, where naked choreotrich ciliates and athecate heterotropic dinoflagellates dominated. There, Gyrodinium spirale and large Gyrodinium/Gymnodinum ( $>40 \mu \mathrm{m}$ ) species contributed $78 \pm 3(\mathrm{SE}) \%$ of heterotropic dinoflagellates and $40 \pm 3$ (SE)\% of the total protozooplankton biomass in samples from the fluorescence maximum and surface water. Potentially mixotrophic ciliates constituted $62 \pm 3$ (SE)\% of the ciliate biomass with the greatest contribution from Mesodinium rubrum. In the southern part of the bay, the biomass of protozooplankton was lower (up to $24 \mu \mathrm{g} \mathrm{C} \mathrm{l}^{-1}$, $\sim 9 \mathrm{cells} \mathrm{ml}^{-1}$ ) and primarily dominated by naked choreotrich ciliates, with a fraction of potentially mixotrophic ciliates of $35 \pm 6(\mathrm{SE}) \%$.

Table 1. Acartia longiremis egg production along the transect studied August 1998

\begin{tabular}{|lccccccc|}
\hline & Stn 1 & Stn 2 & Stn 3 & Stn 4 & Stn 7 & Stn 9 & Stn 11 \\
\hline Eggs female ${ }^{-1} \mathrm{~d}^{-1} \pm \mathrm{SE}$ & $5.1 \pm 1.6$ & $5.9 \pm 1.3$ & $2.8 \pm 0.6$ & $4.7 \pm 2.4$ & $6.3 \pm 2.8$ & $3.3 \pm 1.2$ & $6.2 \pm 1.1$ \\
Cephalothorax length $(\mu \mathrm{m}) \pm \mathrm{SE}$ & $817 \pm 19$ & $819 \pm 9$ & $810 \pm 15$ & $869 \pm 16$ & $881 \pm 12$ & $861 \pm 11$ & $861 \pm 16$ \\
Specific egg production & 0.04 & 0.05 & 0.03 & 0.03 & 0.04 & 0.03 & 0.05 \\
Number of experiments & 13 & 8 & 10 & 8 & 8 & 11 & 11 \\
\hline
\end{tabular}



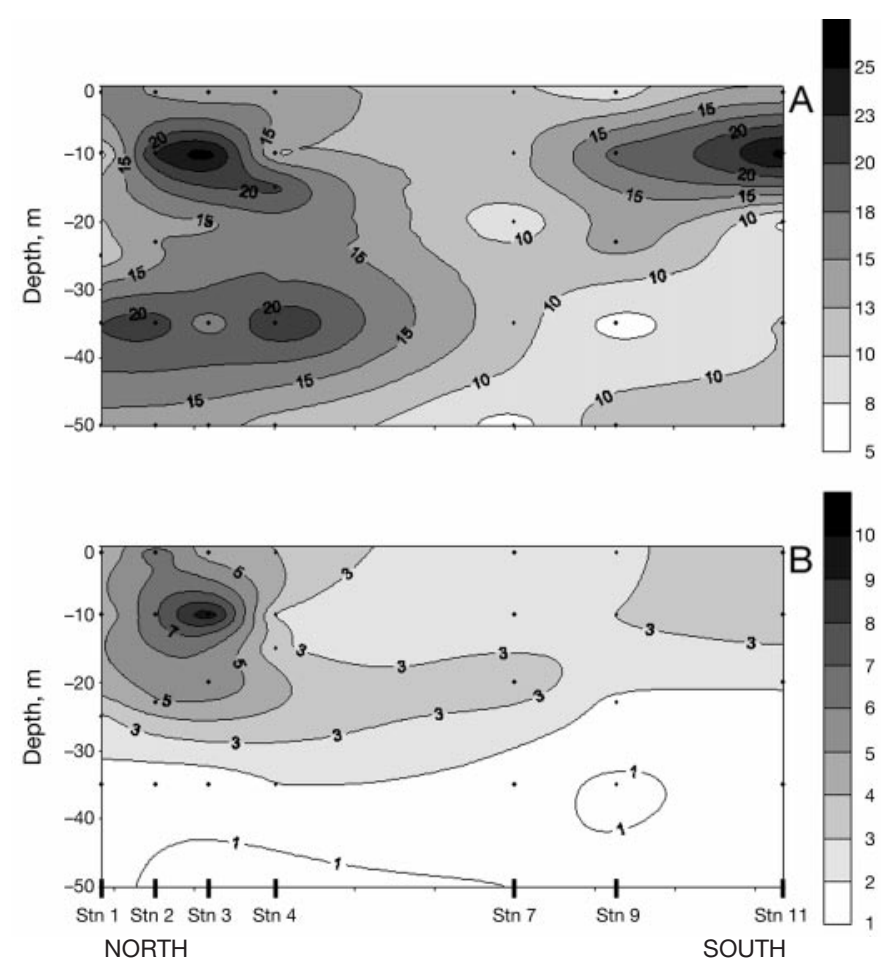

Fig. 5. Distribution of bacterial (A) biomass $\left(\mu \mathrm{g} \mathrm{C}^{-1}\right)$, and (B) production $\left(\mu \mathrm{g} \mathrm{C}^{-1} \mathrm{~d}^{-1}\right)$ along the transect

\section{Mesozooplankton}

The average mesozooplankton biomass was higher in the northern than the southern part of the bay. However, pronounced differences were observed between the stations (Fig. 8). At Stns 3 and 4, which are closest to the islands 'Hundeøerne', the biomasses were more than 3 times higher than at the stations farther away from Hundeøerne probably due to upwelling (Fig. 2) along the islands. The WP-2 net only sampled the larger zooplankters, whereas the harpacticoid copepod Microsetella, nauplii and eggs were lost by the WP-2.

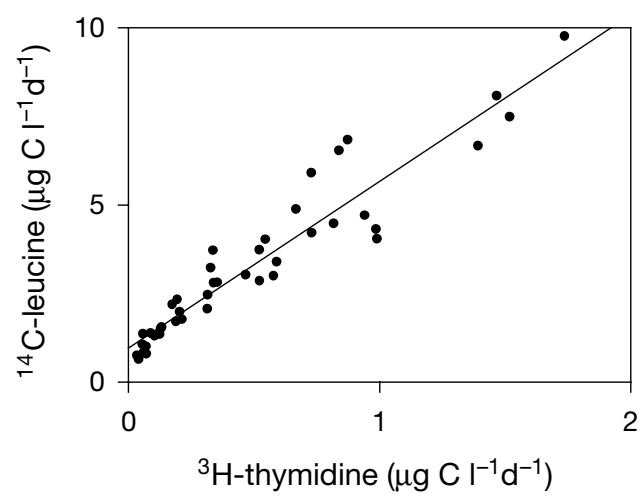

Fig. 6. Correlation between ${ }^{14} \mathrm{C}$-leucine and ${ }^{3} \mathrm{H}$-thymidine incorporation $\left(\mu \mathrm{g} \mathrm{Cl}^{-1}\right)$
Total mesozooplankton community was obtained by combining the catch from the WP-2 with the samples from the $45 \mu \mathrm{m}$ net for these groups, which was efficient at capturing the smaller stages and species, as well as copepod eggs.

Copepods dominated the mesozooplankton biomass, comprising more than $85 \%$ of the biomass, except at Stns 1 and 2, where gastropods contributed $\sim 50 \%$ of the biomass (Fig. 8). Apart from the gastropods, Appendicularia were the only other mesozooplankton notably present (but always comprising less than $1 \mu \mathrm{g} \mathrm{C}^{-1}$ ). Calanus finmarchicus and C. glacialis (copepodite stages I to V) together with Psedocalanus formed $88 \pm 4 \%$ of the copepod biomass.

Egg production of Acartia longiremis (Table 1) varied between $2.8 \pm 0.6$ and $6.2 \pm 2.8(\mathrm{SE})$ eggs female ${ }^{-1} \mathrm{~d}^{-1}$ with no significant differences being observed between stations along the transect (ANOVA, $\mathrm{p}=0.56$ ).

\section{Effect of copepods on DOC production}

Loss of primary production to DOC was calculated from the ${ }^{14} \mathrm{C}$ activity in the filtrate added the activity on the $0.2 \mu \mathrm{m}$ filter corrected for the bacteria on the $0.6 \mu \mathrm{m}$ filter. An average of $45 \pm 1$ (SE) \% of the bacteria were retained on the $0.6 \mu \mathrm{m}$ filter. Virtually no autofluorescence was observed in the 0.2 to $0.6 \mu \mathrm{m}$ fraction. Thus, the activity measured on the $0.2 \mu \mathrm{m}$ filter can be attributed to bacteria only.

The egg production in the DOC production experiment of $5.2 \pm 1.0$ (SE) eggs female ${ }^{-1} \mathrm{~d}^{-1}$ was not significantly different from the results in the egg production experiment (Table 1) ( $t$-test, $\mathrm{p}=0.62$ ). demonstrating that the copepods had been actively feeding. In general, the fraction of primary production lost was higher when copepods were present (Table 2). The difference between the part of primary production lost as DOC in the incubations with and without copepods added relative to the ingestion by the copepods, i.e. percent of ingestion lost as DOC, was $6 \pm 5$ (SE)\%.

Table 2. Fraction of primary production lost in experiments with $45 \mu \mathrm{m}$ filtered water (control) and with addition of copepods (+cop). Significance of differences between experiments with and without addition of copepods: ${ }^{* *} \mathrm{p}<0.01,{ }^{*} \mathrm{p}<0.05$, ns $=$ not significant

\begin{tabular}{|ccccccc|}
\hline \multirow{2}{*}{ Stn } & \multicolumn{2}{c}{$1 \mathrm{~m}$} & & \multicolumn{3}{c|}{ Fluorescence maximum } \\
& Control & + cop & Sign & Control & +cop & Sign \\
\hline 2 & 0.44 & 0.42 & ${ }^{*}$ & 0.58 & 0.75 & ${ }^{* *}$ \\
4 & 0.39 & 0.47 & ${ }^{* *}$ & 0.69 & 0.64 & ${ }^{* *}$ \\
7 & 0.47 & 0.50 & ${ }^{*}$ & 0.80 & 0.88 & $\mathrm{~ns}$ \\
11 & 0.54 & 0.57 & ${ }^{* *}$ & 0.80 & 0.81 & $*$ \\
\hline
\end{tabular}




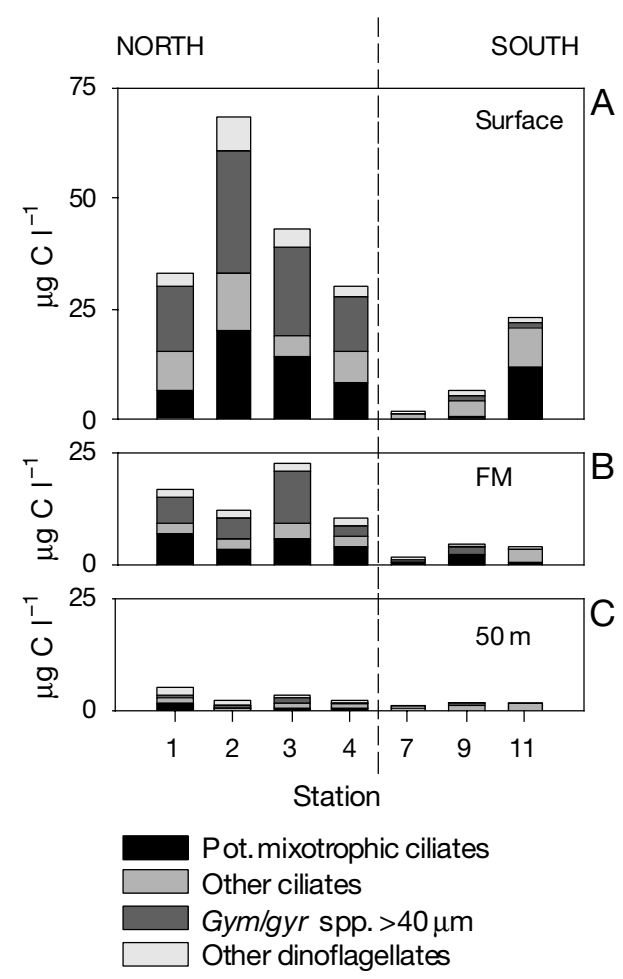

Fig. 7. Distribution of protozooplankton in (A) surface water, (B) water at the depth of maximum fluorescence (FM), and (C) $50 \mathrm{~m}\left(\mu \mathrm{g} \mathrm{C} \mathrm{l}^{-1}\right)$ along the transect

\section{DISCUSSION}

When comparing the southern and northern parts of Disko Bay, clear patterns emerge. In the southern part, where the Polar Current enters the bay, a sill forces deep water into the euphotic zone. Lower temperatures, higher salinity and higher concentrations of nutrients were observed in the surface layer, compared to the northern part, where the water leaves the bay. Differences were also found in the plankton community. Lower biomass levels of phytoplankton, bacteria and zooplankton were observed in the southern part of the bay compared to the northern part. In what follows, the focus will be on the overall differences in plankton communities between the southern and northern parts of the bay. A summary of the average integrated levels of biomass and rates for the 2 areas is given in Fig. 9 .

\section{The 2 plankton communities}

Primary production in Disko Bay has been shown to be limited by nitrogen in the late summer (Nielsen \& Hansen 1999). The water that enters the bay is nutrient rich (Fig. 3). During the circulation around the bay meltwater gradually dilutes this surface layer, reduc-

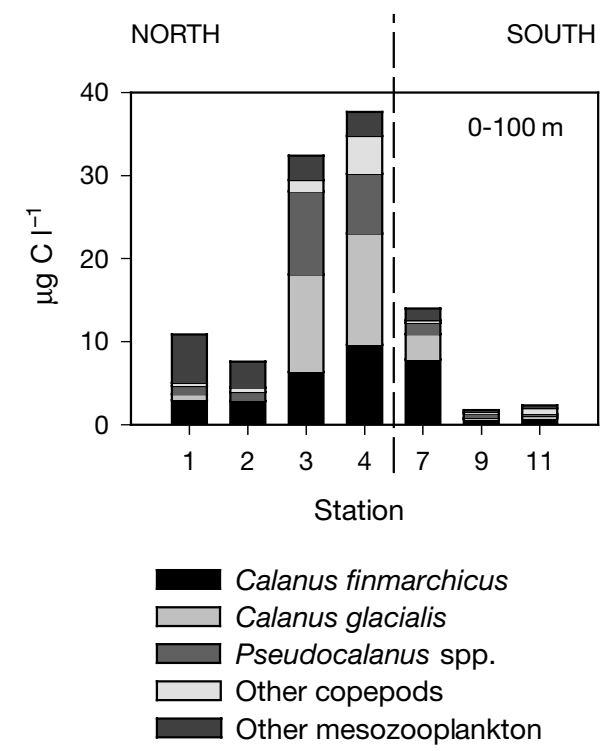

Fig. 8. Average mesozooplankton biomass $\left(\mu \mathrm{g} \mathrm{C}^{-1}\right)$ in the upper $100 \mathrm{~m}$ of the water column

ing its salinity and establishing a stronger stratification. This, in combination with phytoplankton nutrient utilisation, resulted in nutrient depletion of surface water to the north. Below the pycnocline and in the southern part, nutrients were above detection limit.

In the southern part of the bay, small cells $(<11 \mu \mathrm{m})$ dominated the phytoplankton biomass (Fig. 4). The protozooplankton community consisted mainly of ciliates (Fig. 7) which, in general, graze on cells $1 / 8$ of their own size (Hansen et al. 1994), i.e. the $<11 \mu \mathrm{m}$ phytoplankton fraction. In the northern part of the bay, larger phytoplankton cells were relatively more abundant (Fig. 4) along with higher biomass of both ciliates and heterotrophic dinoflagellates (Fig. 7). Heterotrophic dinoflagellates comprised mainly large-sized Gyrodinium spirale and Gyrodinium/Gymnodinum species ( $>40 \mu \mathrm{m})$, which have been documented to have a prey: predator ratio higher than 1:1 (Hansen 1992, Strom \& Strom 1996). This means that these dinoflagellates can graze the large phytoplankton, but they can also prey on other protozooplankters (see references in Hansen 1991). The levels of protozooplankton biomass were comparable to those found in lower latitude waters (Hansen 1991, Nielsen \& Kiørboe 1994, Richardson et al. 1998) and to those reported previously in Disko Bay (Nielsen \& Hansen 1995, Levinsen et al. 1999).

Biomass of copepods was, on average, comparable to protozooplankton biomass both in the southern and northern parts of the bay. Zooplankton biomass was $\sim 3$ times higher in the northern part compared to the southern part of the bay. Copepod community ingestion averaged 1.8 and $0.7 \mu g \mathrm{C} \mathrm{l}^{-1} \mathrm{~d}^{-1}$ in the 

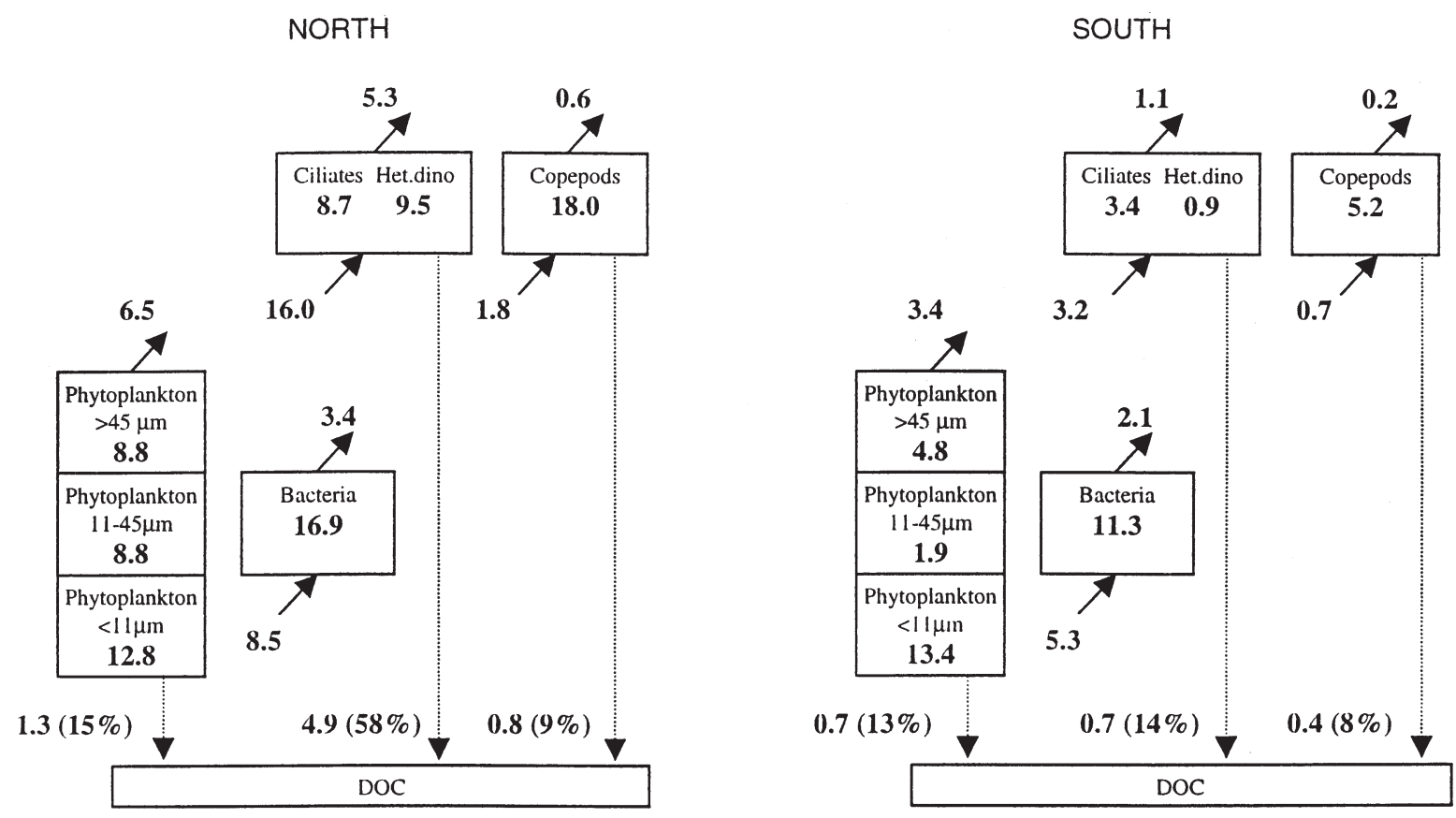

Fig. 9. Carbon flow budgets of the pelagic food web in the northern and southern parts of Disko Bay in August 1998. Data presented in Figs. 2C, 4, 5, 7 \& 8 were integrated from 0 to $100 \mathrm{~m}$ for copepods and 0 to $50 \mathrm{~m}$ for all others. Numbers in boxes show average biomasses $\left(\mu \mathrm{g} \mathrm{Cl}^{-1}\right)$. Arrows represent rates $\left(\mu \mathrm{g} \mathrm{Cl}^{-1} \mathrm{~d}^{-1}\right)$. Solid arrows pointing toward a box represent carbon demand while those leaving represent production. (…ㄱ) Production of DOC. Numbers in brackets are percent of bacterial carbon demand fulfilled by the different sources of DOC

north and south, respectively, while the corresponding protozooplankton community ingestion was 16 and $3.2 \mu \mathrm{g} \mathrm{C} \mathrm{l}^{-1} \mathrm{~d}^{-1}$, respectively. Thus, considering the higher turnover of protozooplankton, their grazing impact was potentially most important.

The total zooplankton ingestion (copepods plus protozooplankton) was 58 and $20 \%$ of the phytoplankton biomass per day in the northern and southern parts of the bay, respectively. This suggests that the food web in the north could, to a lesser extent than the one in south, be supported by phytoplankton, and agrees with the idea of a trophic structure that comprises many levels within the zooplankton community in the north, as discussed above.

In summary, the hydrography in Disko Bay in the late summer caused development of 2 distinct pelagic communities: a plankton community with a complex trophic structure that may include omnivory in the north and a simpler herbivorous food web in the south. Differences in the food webs were likely under physical control, i.e. stratification versus upwelling.

\section{Correlations between bacterial production and plankton biomasses}

The pronounced differences between the plankton communities in the northern and southern parts of the bay apparently led to differences in the importance of factors influencing the bacterial community production. First, the bacterial production was 1.6 times higher in the northern than in the southern part of the bay. Sec-

Table 3. The slope, intercept and correlation coefficient of the regression between protozoo- and phytoplankton biomass and bacterial production. ${ }^{* *} \mathrm{p}<0.01,{ }^{*} \mathrm{p}<0.05, \mathrm{~ns}=$ not significant

\begin{tabular}{|c|c|c|c|c|c|c|c|c|c|c|}
\hline & \multicolumn{5}{|c|}{ Phytoplankton } & \multicolumn{5}{|c|}{ Protozooplankton } \\
\hline & Slope & Intercept & $\mathrm{r}^{2}$ & $\mathrm{n}$ & Sign & Slope & Intercept & $\mathrm{r}^{2}$ & $\mathrm{n}$ & Sign \\
\hline Total & 0.03 & 1.04 & 0.40 & 21 & $* *$ & 0.08 & 1.72 & 0.63 & 21 & ** \\
\hline South & 0.03 & 0.72 & 0.20 & 9 & $\mathrm{~ns}$ & 0.07 & 1.80 & 0.26 & 9 & ns \\
\hline North & 0.03 & 1.08 & 0.36 & 12 & $*$ & 0.08 & 1.63 & 0.64 & 12 & $* *$ \\
\hline
\end{tabular}


ond, differences were found in correlations between bacterial production and plankton biomass (Table 3). Using all data (north and south combined) produces a significant correlation of both protozooplankton and phytoplankton biomass to bacterial production, whereas mesozooplankton biomass or production showed no significant correlation. In the southern region no correlations were found between phyto- or protozooplankton, while in the northern region bacterial production correlated strongly to protozooplankton biomass and weakly to phytoplankton biomass. No correlations were found between the proto- and phytoplankton.

The usefulness of information gained by correlating bacterial production and plankton biomass depends on causality. Bacterial production is controlled by the availability of resources, i.e. carbon or nutrients. The availability of carbon is usually assumed to be most important (Kirchman 1994), but shortage of $\mathrm{N}$ and $\mathrm{P}$ has also been suggested to limit bacterial growth (Heinänen \& Kuparinen 1992, Kroer 1993, Zweifel et al. 1993). Predation (Pace \& Cole 1994) and temperature (Pomeroy \& Deibel 1986) may sometimes limit bacterial community production to levels lower than sustainable by resources alone.

The correlation between bacterial production and protozooplankton biomass in the northern part of the bay can be explained by the production of resources for bacteria by protozooplankton, but may also be governed by protozooplankton grazing on bacterial predators, or on phytoplankton, which potentially compete with bacteria for nutrients. The surface water in the northern part of the bay is nutrient depleted (Fig. 3). This indicates that there could be competition for nutrients. On the other hand, the large protozooplankton community suggests that high nutrient turnover rates and bacterial production were also found to correlate positively with the phytoplankton biomass. Since there was no difference in the biomass of potentially bacterivorous flagellates in the northern and southern parts, and an estimate of their clearance capacity shows that they can clear less than $1 \%$ of the water column per day, these are probably not the cause of the differences between the northern and southern parts. The slopes of the regression lines between phyto- or protozooplankton and bacterial production (0.03 and 0.08, respectively, Table 3 ) indicate that the protozooplankton is potentially more important than the phytoplankton in providing substrate for the bacteria.

\section{Carbon flow scenarios}

To evaluate the importance of possible sources of carbon for the bacterial communities, 2 carbon flow scenarios were constructed using an average of inte- grated values of biomasses and rates from the northern and southern parts, respectively. The 2 scenarios will be used to explain the differences in correlations shown above. The principal sources of DOC are exudates from phytoplankton and zooplankton grazing. To estimate these sources, several assumptions have been made. Nevertheless, by considering ranges for the rates, the calculations are useful to compare the 2 scenarios and to investigate the different sources of DOC. The estimated DOC production by the different plankton organisms is summarised in Fig. 9, calculated as mean values of the ranges considered below.

The contribution from phytoplankton can be calculated assuming they release $5 \%$ of their carbon biomass per day (Bjørnsen 1988), i.e. 1.8 and $1.0 \mu \mathrm{g} \mathrm{C}^{-1} \mathrm{~d}^{-1}$ in the northern and southern parts, respectively. Alternatively, the estimated primary production can be used together with the average of $13 \%$ of total fixation lost as DOC obtained from a compilation of data by Baines \& Pace (1991). Higher values of exudation have been reported especially from field experiments probably reflecting the problems of omitting small grazers from the experiments. The estimates based on primary production are 0.8 and $0.4 \mu \mathrm{g} \mathrm{C}^{-1} \mathrm{~d}^{-1}$ in the northern and southern parts, respectively.

Protozooplankton ingestion can be calculated using the growth rates obtained by Levinsen et al. (1999) or alternatively by assuming a clearance capacity of $10^{5}$ body volume $\mathrm{h}^{-1}$ and that the food available for ciliates and dinoflagellates is phytoplankton less than and larger than $11 \mu \mathrm{m}$, respectively. Strom et al. (1997) estimated that, on average, $32 \%$ of the carbon was lost by an ingestion event working with ciliates and dinoflagellates in laboratory. Thus, using this value and the different estimates of ingestion yields a contribution from protozooplankton of between 4.6 and $9.2 \mu \mathrm{g} \mathrm{C} \mathrm{l}^{-1} \mathrm{~d}^{-1}$ in the north and between 0.4 and $1.4 \mu \mathrm{g} \mathrm{C}^{-1} \mathrm{~d}^{-1}$ in the south.

Based on laboratory experiments with copepods grazing on small and large cells, between 20 (Strom et al. 1997) and $60 \%$ (E.F.M. \& T.G.N. unpubl.) of ingested carbon has been reported to be released as DOC. Using these values and ingestion rates determined from our egg production experiments DOC produced by copepods ranged between 0.4 and $1.2 \mu \mathrm{g} \mathrm{C}^{-1} \mathrm{~d}^{-1}$ in the north and between 0.2 and $0.6 \mu \mathrm{g} \mathrm{C}^{-1} \mathrm{~d}^{-1}$ in the south.

A direct measure of the effect of copepods on DOC production during the present investigation was the increased fraction of primary production resulting in the dissolved fraction when copepods were present (Table 2). A rough estimate of $6 \%$ of copepod ingestion lost as DOC was obtained when comparing the difference in the loss of $\mathrm{DO}^{14} \mathrm{C}$ in bottles with and without copepods to the ingestion performed by the copepods. 
Eppley et al. (1981) also evaluated zooplankton production of DOC using ${ }^{14} \mathrm{C}$ labelled phytoplankton, but did not show an increase in ${ }^{14} \mathrm{C}$ in the bacteria and the DOC pool in the presence of copepods. In their studies however, the presence of copepods did lead to increases in concentrations of dissolved primary amines and saccharides as well as bacterial production, and it was suggested that the greater part of the carbon flowing from zooplankton to bacteria was not ${ }^{14} \mathrm{C}$ labelled. This may also have been the situation in the present experiment.

Approximately $50 \%$ of the phytoplankton biomass in the experimental bottles would have been grazed if the copepod diet consisted only of phytoplankton. This was not the case; i.e. Acartia longeremis probably fed on protozooplankton in addition to phytoplankton. This is supported by Levinsen et al. (2000), who found that the share of ciliates and dinoflagellates to ingestion estimated from egg production was up to 25 and $7 \%$, respectively, working with $A$. longeremis at Stns 7 and 11 during the same cruise. Thus, unlabelled DOC was probably produced. If the feeding of copepods on protozooplankton was substantial, it could also lead to an underestimation of the loss caused by copepods, because the biomass of protozooplankton, and thus the feeding activity of protozooplankton, would be highest in the incubations without copepods. This could cause an increase in DOC due to protozooplankton feeding in the bottles without copepods, compared to the bottles with copepods.

Support for this hypothesis may be drawn from the negative effect of copepods on the DOC production in surface samples at Stn 2 (Table 2). This is also where the highest protozooplankton biomasses were found (Fig. 7), suggesting that a substantial part of the copepod diet there might have consisted of protozooplankton. Also, results from the fluorescence maximum at Stn 4 indicate a negative effect of copepods on DOC production. The measurement of fractionated chl $a$ (Fig. 4) shows that very little is available in the 11 to $45 \mu \mathrm{m}$ fraction, suggesting that a great part of the copepod diet might have been protozooplankton as well. The above examples may provide circumstantial support for the suggestion by the carbon flow scenario of the importance of protozooplankton in production of DOC.

In summary, the carbon flow scenarios (Fig. 9) suggest that, in the northern part of Disko Bay, the major proportion of the DOC production originated from protozooplankton, while in the southern region, DOC originating directly from phytoplankton and from mesozooplankton grazing was as important as the contribu- tion from protozooplankton. This agrees with the correlations found between plankton biomass and bacterial production (Table 3). These also indicated the importance of protozooplankton to bacteria in the north, but that no plankton groups were significantly correlated to bacterial production in the south.

\section{Supply of carbon compared to bacterial carbon demand}

The extent to which the different DOC contributions can fulfil the bacterial carbon demand in the southern and northern parts of the bay can be estimated from bacterial production. In the present experiment, a factor of 5 was found between estimates made with ${ }^{14} \mathrm{C}$-leucine and ${ }^{3} \mathrm{H}$-thymidine (Fig. 6). The choices of conversion factors are critical and the added low ${ }^{3} \mathrm{H}$-thymidine concentration may not have been sufficient to saturate bacterial uptake. Therefore the value calculated from ${ }^{14} \mathrm{C}$-leucine uptake is used for estimating bacterial carbon demand. A growth efficiency of $40 \%$ is assumed (Bjørnsen \& Kuparinen 1991). This value is chosen conservatively in the higher end of the range reported for natural assemblages of marine bacteria (Carlson \& Ducklow 1996); i.e. the bacterial carbon demand may by higher.

Bacterial carbon demand was apparently more balanced by the DOC production in the northern part than in the southern part of the bay (Fig. 9). DOM has been shown to accumulate through the productive season at lower latitudes (Zweifel et al. 1995, Carlson et al. 1998). Low temperatures limiting the bacterial production during spring bloom in the Arctic (Pomeroy \& Deibel 1986) could lead to accumulation of DOM that could possibly be used when temperatures are higher, i.e. in late summer.

An estimate of the production of substrates for bacteria by zooplankton and phytoplankton in the northern part of Disko Bay during spring bloom can be made using the data provided by Nielsen \& Hansen (1995)

Table 4 . The potential importance of copepods, protozooplankton and phytoplankton in production of carbon for bacteria in Disko Bay during and after the spring bloom 1992. Numbers in brackets are percent of bacterial carbon demand fulfilled by the different sources. Based on Nielsen \& Hansen (1995)

\begin{tabular}{|lcccc|}
\hline & $\begin{array}{c}\text { Spring (during bloom) } \\
(\text { June 22-28, 1992) }\end{array}$ & $\begin{array}{c}\text { Spring (after bloom) } \\
(\text { July 1-6, 1992) }\end{array}$ \\
\hline $\begin{array}{l}\text { Bacterial carbon demand } \\
\left(\mu \mathrm{C} \mathrm{C}^{-1} \mathrm{~d}^{-1}\right)\end{array}$ & 2 & & & 6.5 \\
Sources of DOC $\left(\mu \mathrm{C} \mathrm{l}^{-1} \mathrm{~d}^{-1}\right)$ & & & & \\
$\begin{array}{l}\text { Phytoplankton } \\
\text { Protozooplankton }\end{array}$ & 3.8 & $(190)$ & 2.4 & $(37)$ \\
Copepods & 6.4 & $(320)$ & 5.8 & $(89)$ \\
& 1.4 & $(143)$ & 1.0 & $(34)$ \\
\hline
\end{tabular}


and the same assumptions as above about the production of DOC (Table 4).

Comparing the relative importance of planktonic organisms reveals that both the production of DOC by phytoplankton and copepods is higher in spring than in the late summer. Copepods may be even more important if it is considered that phytoplankton cells are larger in spring (Nielsen \& Hansen 1995) than in late summer, i.e. that in spring the loss by sloppy feeding will be greater (E.F.M. \& T.G.N. unpubl.). The total DOC production during and after the bloom is similar, although in the post-bloom period, cell lysis may lead to higher exudation of DOC which would increase the contribution from phytoplankton. In the early spring it seems that the production of DOC by the plankton community can more than fulfil the bacterial carbon demand. During the 2 wk period of the study the bacterial carbon demand almost tripled, presumably in connection with the increasing temperature leading to a more balanced proportion between production and consumption of DOC. Thus, this estimate suggests a potential accumulation of DOC during the early spring bloom, which can be used later by the bacteria.

\section{Conclusion}

The present study documented the tight coupling between hydrography and plankton community structure. Two different plankton communities were found in the southern and northern parts of Disko Bay, reflecting the entrance of the Polar Current to the bay in the southern part and its departure in the northern part together with run off from the Ilulissat glacier. A plankton community with higher biomasses of all organisms and an apparently more complex trophic structure was found in the northern part, compared to a simpler herbivorous food web in the southern part of the bay. Bacterial production was also higher in the northern region. Protozooplankton played a key role not only as grazers but also as producers of substrates for the bacterial community.

Acknowledgements. The Danish National Research Council Grant No. 9801391, No. 9501038 and the European Union Contract No. Mas3-CT97-0148 supported the present study. E.F.M. was supported by Anders Månsson og Hustrus legat. We wish to thank Birgit Søborg for excellent technical assistance during the fieldwork, the crew of the RV 'Adolf Jensen' for help during sampling, and Ole Schou Hansen and Dorte Grastrup-Hansen for counting protozooplankton and phytoplankton. In addition we would like to thank Benni Winding Hansen, Morten Søndergaard, Katherine Richardson, Henrik Levinsen, Lasse Riemann and Colin Stedmon for discussion and constructive criticism, and Jefferson T. Turner and an anonymous reviewer for editorial suggestions on earlier versions of this manuscript.

\section{LITERATURE CITED}

Andersen P (1988) The quantitative importance of the 'Microbial loop' in the marine pelagic: a case study from the North Bering/Chukchi seas. Arch Hydrobiol Beih Ergeb Limnol 31:243-251

Baines SB, Pace ML (1991) The production of dissolved organic matter by phytoplankton and its importance to bacteria: patterns across marine and freshwater systems. Limnol Oceanogr 36:1078-1090

Bjørnsen PK (1988) Phytoplankton exudation of organic matter: why do healthy cells do it? Limnol Oceanogr 33(1):151-154

Bjørnsen PK, Kuparinen J (1991) Determination of bacterioplankton biomass, net production and growth efficiency in the Southern Ocean. Mar Ecol Prog Ser 71:185-194

Bratbak G, Dundas I (1984) Bacterial dry matter content and biomass estimations. Appl Environ Microbiol 48:755-757

Carlson CA, Ducklow HW (1996) Growth of bacterioplankton and consumption of dissolved organic carbon in the Sargasso Sea. Aquat Microb Ecol 10:69-85

Carlson CA, Ducklow HW, Hansell DA, Smith WO Jr (1998) Organic carbon partitioning during spring phytoplankton blooms in the Ross Sea polynya and the Sargasso Sea. Limnol Oceanogr 43(3):375-386

Cole JJ, Findlay S, Pace ML (1988) Bacterial production in fresh and saltwater ecosystems: a cross-system overview. Mar Ecol Prog Ser 43:1-10

Edler L (1979) Recommendations for marine biological studies in the Baltic Sea. Baltic Mar Biol Publ 5:1-38

Eppley RW, Horrigan SG, Fuhrman JA, Brooks ER, Price CC, Sellner K (1981) Origins of dissolved organic matter in Southern California coastal waters: experiment on the role of zooplankton. Mar Ecol Prog Ser 6:149-159

Ferrier-Pagès C, Karner M, Rassoulzadegan F (1998) Release of dissolved amino-acids by flagellates and ciliates grazing on bacteria. Oceanol Acta 21(3):485-494

Fuhrman JA, Azam F (1982) Thymidine incorporation as a measure of heterotrophic bacterioplankton production in marine surface waters: evaluation and field results. Mar Biol 66:109-120

Grashoff K (1976) Methods for seawater analyses. Weinheim, New York

Haas LW (1982) Improved epifluorescence microscopy for observing planktonic microorganisms. Ann Inst Oceanogr 58:261-266

Hansen B, Bjørnsen PK, Hansen PJ (1994) The size ratio between plankton predators and their prey. Limnol Oceanogr 39:395-403

Hansen BW, Nielsen TG, Levinsen H (1999) Plankton community structure and carbon cycling on the western coast of Greenland during the stratified summer situation. III. Mesozooplankton. Aquat Microb Ecol 16:233-249

Hansen PJ (1991) Quantitative importance and trophic role of the heterotrophic dinoflagellates in a coastal pelagic food web. Mar Ecol Prog Ser 73:253-261

Hansen PJ (1992) Prey size selection, feeding rates and growth dynamics of heterotrophic dinoflagellates with special emphasis on Gyrodinium spirale. Mar Biol 144: 327-334

Hansen PJ, Bjørnsen PK, Hansen BW (1997) Zooplankton grazing and growth: scaling within the $2-2000-\mu \mathrm{m}$ body size range. Limnol Oceanogr 42:687-704

Heinänen A, Kuparinen J (1992) Response of bacterial thymidine and leucine incorporation to nutrient $\left(\mathrm{NH}_{4}, \mathrm{PO}_{3}\right)$ and carbon (sucrose) enrichment. Arch Hydrobiol Beih Ergeb Limnol 37:241-251

Hobbie JE, Daley RJ, Jaspers S (1977) Use of nucleopore fil- 
ters for counting bacteria by epifluorescence. Appl Environ Microbiol 33:1228-1255

Jespersen AM, Christoffersen K (1987) Measurements of chlorophyll a from phytoplankton using ethanol as extraction solvent. Arch Hydrobiol 109:445-454

Jumars PA, Penry DL, Baross JA, Perry MJ, Frost BW (1989) Closing the microbial loop: dissolved carbon pathway to heterotrophic from incomplete ingestion, digestion and absorption in animals. Deep-Sea Res 36:483-495

Kiørboe T, Møhlenberg F, Hamburger K (1985) Bioenergetics of the planktonic copepod Acartia tonsa: relation between feeding, egg production and respiration, and composition of specific dynamic action. Mar Ecol Prog Ser 26:85-97

Kirchman DL (1994) The uptake of inorganic nutrients by heterotrophic bacteria. Microb Ecol 28:255-271

Kirchman DL, K'nees E, Hodson RE (1985) Leucine incorporation and its potential as a measure of protein synthesis by bacteria in natural aquatic systems. Appl Environ Microbiol 49:599-607

Kroer N (1993) Bacterial growth efficiency on natural dissolved organic matter. Limnol Oceanogr 38(6):1283-1290

Levinsen H, Nielsen TG, Hansen B (1999) Plankton community structure and carbon cycling on the western coast of Greenland during the stratified summer situation. II. Ciliates and heterotrophic dinoflagellates. Aquat Microb Ecol 16:217-232

Levinsen H, Turner JT, Nielsen TG, Hansen B (2000) On the trophic coupling between protists and copepods in arctic marine ecosystems. Mar Ecol Prog Ser (in press)

Markager S, Vincent WF, Tang EPY (1999) Carbon fixation by phytoplankton in high Arctic lakes: implications of low temperature for photosynthesis. Limnol Oceanogr 44:597-607

Nagata T, Kirchman DL (1992) Release of macromolecular organic complexes by heterotropic marine flagellates. Mar Ecol Prog Ser 83:233-240

Nielsen TG, Hansen B (1995) Plankton community structure and carbon cycling on the western coast of Greenland during and after the sedimentation of a diatom bloom. Mar Ecol Prog Ser 125:239-257

Nielsen TG, Hansen BW (1999) Plankton community structure and carbon cycling on the western coast of Greenland during the stratified summer situation. I. Hydrography, phytoplankton and bacterioplankton. Aquat Microb Ecol 16:205-216

Nielsen TG, Kiørboe T (1994) Regulation of zooplankton biomass and production in a temperate coastal environment. 2. Ciliates. Limnol Oceanogr 39(1):21-36

Pace ML, Cole JJ (1994) Comparative and experimental approaches to top-down and bottom-up regulation of bacteria. Microb Ecol 28:181-193

Peduzzi P, Herndl GJ (1992) Zooplankton activity fueling the microbial loop: differential growth response of bacteria from oligotrophic and eutrophic waters. Limnol Oceanogr $37: 1087-1092$

Editorial responsibility: John Dolan,

Edgewater, Maryland, USA
Pomeroy LR, Deibel D (1986) Temperature regulation of bacterial activity during the spring bloom in Newfoundland coastal waters. Science 233:359-361

Pomeroy LR, Wiebe WJ (1988) Energetics of microbial food webs. Hydrobiologia 159:7-18

Pomeroy LR, Wiebe WJ, Deibel D, Thompson RJ, Rowe GT, Pakulski JD (1991) Bacterial responses to temperature and substrate concentration during the Newfoundland spring bloom. Mar Ecol Prog Ser 75:143-159

Poulet SA, Williams R, Conway DVP, Videau C (1991) Cooccurrence of copepod and dissolved free amino acids in shelf sea waters. Mar Biol 108:372-385

Richardson K, Nielsen TG, Pedersen FB, Heilmann JP, Løkkegård B, Kaas H (1998) Spatial heterogeneity in the structure of the planktonic food web in the North Sea. Mar Ecol Prog Ser 168:197-211

Riemann B, Bjørnsen PK, Newell S, Fallon R (1987) Calculation of cell production of coastal marine based on measured incorporation of ${ }^{3} \mathrm{H}$-thymidine. Limnol Oceanogr 32: 471-476

Roman RM, Ducklow HW, Fuhrman JA, Garside C, Glibert PM, Malone TC, McManaus GB (1988) Production, consumption and nutrient cycling in a laboratory mesocosm. Mar Ecol Prog Ser 42:39-52

Sherr EB, Sherr BF, Fessenden L (1997) Heterotrophic protists in the Central Arctic Ocean. Deep-Sea Res II 44(8): 1665-1682

Simon M, Azam F (1989) Protein content and protein synthesis rates of planktonic marine bacteria. Mar Ecol Prog Ser 51:201-213

Strickland JDH, Parsons TR (1968) A practical handbook of seawater analysis. Bull Fish Res Board Can 167

Strom SL, Strom MW (1996) Microplankton growth, grazing, and community structure in the northern Gulf of Mexico. Mar Ecol Prog Ser 130:229-240

Strom SL, Benner R, Ziegler S, Dagg MJ (1997) Planktonic grazers are a potentially important source of marine dissolved organic carbon. Limnol Oceanogr 42:1364-1374

Thingstad F, Martinussen I (1991) Are bacteria active in the cold pelagic ecosystem of the Barents Sea? Polar Res 10(1): 255-266

Tranvik L (1994) Colloidal and dissolved organic matter excreted by a mixotropic flagellate during bacterivory and autotrophy. Appl Environ Microbiol 60(6):1884-1888

Yager PL, Deming JD (1999) Pelagic microbial activity in an arctic polynya: testing for temperature and substrate interactions using a kinetic approach. Limnol Oceangr 44: 1882-1893

Zweifel UL, Norrman B, Hagström ^̊ (1993) Consumption of dissolved organic carbon by marine bacteria and demand for inorganic nutrients. Mar Ecol Prog Ser 101:23-32

Zweifel UL, Wikner J, Hagström A, Lundberg E, Norrman B (1995) Dynamics of dissolved organic carbon in a coastal ecosystem. Limnol Oceangr 40:299-305

Submitted: February 22, 2000; Accepted: May 8, 2000

Proofs received from author(s): June 22, 2000 